Int. Archs Allergy appl. Immun. 1987;84:I-V

\title{
Contents, Vol. 84, 1987
}

\section{No. 1}

Original Paper

Parasitic Modulation of Host Immune Mechanisms in Schisto-somiasis

Attallah, A.M.; Abdul-Aal, G.M.; Urritia-Shaw, A.; Mur-

rell, K.D.; Fleisher, T.A.; Vannier, W.E 1

Immunological Monitoring and Early Prediction of Rejection in Renal Allograft Recipients

Attallah, A.M.; Abdelghaffar, H.; Alghraoui, F.; Fawzy, A.;

Alijani, M.R.; Mahmoud, L.A.; Ghoneim, M.A.; Helfrich,

G.B 10

Evidence for an Activated Subpopulation of T8-Bearing Cells in Male Homosexuals with

Lymphadenopathy Hillman, J.; Russo, C; Weksler, M.E.; Siskind, G.W. . 18

Allergens in Hymenoptera Venom. XIX. Allergy to Vespa cra-

bro, the European Hornet

Hoffman, D.R.; Jacobson, R.S.; Zerboni, R 25

Abnormality in Actin Polymerization Associated with Defec

tive Chemotaxis in Neutrophils from Neonates

Sacchi, F.; Augustine, N.H.; Coello, M.M.; Morris, E.Z.;

Hill, H.R

32

Effects of Aerosol Antigen Challenge in vivo on Responsive

ness of Guinea Pig Tracheal and Parenchymal Strips in

vitro to Contractile Agonists

Compton, M.R.; Seale, J.P.; Shaw, J 40

Transient Elevation of Serum IgE after Allogeneic Bone-Marrow Transplantation Korver, K.; Schellekens, P.T.A.; Dooren, L.J.; Vossen, J.M. 45

Antigenic/Allergenic Analysis of Basidiomycete Cap, Mycelia, and Spore Extracts Weissman, D.N.; Halmepuro, L.; Salvaggio, J.E.; Lehrer, S.B. 56

Canine Unilateral Lung Transplantation: Effect of Ciclosporin

A on the Frequency of Donor-Lytic Lymphocytes

Kirby, J.A.; Reader, J.A.; Corbishley, CM.; Pepper, J.R.;

Hudson, L 62

T Cell Reactivity of Conjugates of N-Formyl-Methionyl-Leu-

cyl-Phenylalanine and Rye-Grass Pollen Allergens

Wheeler, A.W.; Whittall, N.; Cook, R.M.; Spackman,

V.M.; Moran, D.M 69

Oral Hyposensitisation with Enteric-Coated Allergens as Ex tension Therapy following a Basic Subcutaneous Course of

Injections

Horak, F.; Wheeler, A.W 74 
Induction of Human Immunoglobulin Synthesis (IgG, IgA) by

the Novel, T Cell Independent Mitogen Cytophaga allergi-

nae Endotoxin

Alevy, Y.G.; Compas, M.B 79

Effect of Glycoprotein-Processing Inhibitors on the Mouse IgE

Binding Capacity of Rat Basophilic Leukemia Cells

Gavériaux, C; Loor, F. 85

Toluene Diisocyanatc Respiratory Reactions. I. Reassessment of the Problem

Patterson, R.; Hargreave, F.E.; Grammer, L.C.; Harris,

K.E.; Dolovich, J 93

Short Communications

Calcium Channels and Histamine Release from Mast Cells

West, G.B 101

Are Macrophages the Target of Antigenic Competition be

tween Different Epitopes of a Hapten-Carrier Conjugate?

Neveu, P.J 103

Book Reviews $\quad 108$

No. 2

Original Paper

IgG Subclass Responses and Immediate Skin Sensitivity in

Guinea-Pigs with Chronic Relapsing Experimental Allergic

Encephalomyelitis

Walls, A.F.; Suckling, A.J.; Rumsby, M.G 109

Allergic Reactivity of Parthenium hysterophorus (Santa Maria

Feverfew) Pollen: An Unrecognized Allergen

Wedner, H.J.; Zenger, V.E.; Lewis, W.H 116

Nasal Mucosal Mast Cells and Histamine in Hay Fever. Effect

of Topical Glucocorticoid Treatment

Pipkorn, U.; Enerbäck, L 123

Immunomodulatory Effects of Orally-Administered Saponins

and Nonspecific Resistance against Rabies Infection

Chavali, S.R., Campbell, J.B 129

Inhibition of Interleukin 2 by Serum in Healthy Individuals and in Patients with Autoimmune

Disease Fukushima, T.; Kobayashi, K.; Kasama, T.; Kasahara, K.; Tabata, M.; Sekine, F.;

Negishi, M.; Ide, H.; Takahashi, T. 135

Macrophage Activation by Micropolyspora faeni Does Not

Suppress Anamnestic Pulmonary Immunologic Reactivity

Schuyler, M.R.; Pensky, J 142

Plasma Levels of Leukotrienes C4 and D4 during Wheezing Attack in Asthmatic Patients

Õkubo, T.; Takahashi, H.; Sumitomo, M.; Shindoh, K.;

Suzuki, S 149

Modulating Effects of Hepar $3 / 8 n$ Preparations on the DNA Syn

thesis Response of Human Peripheral Blood T Lympho

cytes Activated by Mercuric Chloride and Nickel Sulfate

Nordlind, K 156 
Human Cytotoxic T-Cells against Measles Virus-Infected and Myelin Basic Protein-Coated Targets Are Cross-Reactive Matossian-Rogers, A.; Dos Santos, A.; Festenstein, H. .. 159

IV

Contents

Crawfish and Lobster Allergens: Identification and Structural

Similarities with Other Crustacea

Halmepuro, L.; Salvaggio, J.E.; Lehrer, S.B 165

Humoral Immune Response to Cow's Milk in Children with

Cow's Milk Allergy. Relationship to the Time of Clinical

Response to Cow's Milk Challenge

Firer, M.A.; Hoskings, C.S.; Hill, D.J

173

Activation of the Alternative Pathway of Human Complement by Sulfhydryl Compounds of Analytic and Therapeutic Use von Zabern, I.; Nolte, R 178

Eosinophil Chemotactic Lymphokine Produced by Spleen Cells of Schistosoma japonicum-lniecXeå Mice. III. Isola tion and Characterization of Two Distinctive Eosinophil Chemotactic Lymphokines Directed against Different Maturation Stages of Eosinophils

Owhashi, M.; Nawa, Y 185

Variability of Antigenicity/Allergenicity in Different Strains of Altemaria alternata

Steringer, I.; Aukrust, L.; Einarrson, R 190

Detection of IgG Subclass-Specific Anti-IgE Antibodies in

Normal and Atopic Individuals

Wilson, P.B.; Fairfield, J.E.; Beech, N 198

Neuropeptide Regulation of Human Thymocyte, Guinea Pig T

Lymphocyte and Rat B Lymphocyte Mitogenesis

Söder, O.; Hellström, P.M 205

Short Communication

Kidney Mast Cells, IgE and Release of Inflammatory Media tors Capable of Altering Renal Haemodynamics Assem, E.S.K.; Abdullah, N.A.; Cowie, A.G.A

No. 3

Original Paper

Interferon and B2-Microglobulin in Patients with Common

Variable Immunodeficiency or Selective IgA Deficiency

Strannegård, Ö.; Björkander, J.; Hellstrand, K.; Pacsa, A.;

Hermodsson, S.; Hanson, L. $\AA$

Mitogenic Effect of Beryllium Sulfate on Mouse B Lympho

cytes but Not $\mathrm{T}$ Lymphocytes in vitro

Newman, L.S.; Campbell, P.A 223

Allergenic Cross-Reactivity of Egg-White and Egg-Yolk Proteins. An in vitro Study

Walsh, B.J.; Elliott, C; Baker, R.S.; Barnett, D.; Burley,

R.W.; Hill, D.J.; Howden, M.E.H 228 
Effect of Fish-Oil-Supplemented Diet on Inflammation and Immunological Processes in Rats

Yoshino, S.; Ellis, E.F233

Cellular Composition of Peripheral Lymph and Skin of Sheep

Defined by Monoclonal Antibodies

Hein, W.R.; McClure, S.J.; Miyasaka, M 241

Differential Effects of Histamine Receptor Antagonists on

Human Natural Killer Cell Activity

Hellstrand, K.; Hermodsson, S 247

Depression of Lymph Node Cell Proliferation Induced by Oxazolone Kimber, L; Pierce, B.B.;

Mitchell, J.A.; Kinnaird, A. . . 256

Anti-Idiotype Antibody as a Mirror Image of the Paratope of the Original Antibody

Furusawa, S.; Okitsu-Negishi, S.; Yoshino, K.; Mizoguchi,

M.; Noguchi, Y 263

A Specific Enzyme-Linked Immunosorbent Assay for Defini

tion of the IgG Antibody Response to Disulphide-Conju-

gated D-Penicillamine in the Rabbit

Foster, A.L.; Park, B.K.; Coleman, J.W 271

Drugs as Allergens: The Molecular Basis of IgE Binding to Thiopentone Harle, D.G.; Baldo, B.A.; Smal, M.A.; Fisher, M.M. ... 277

Effects of Antigen Challenge on Intestinal Permeability and

Morphology in Rats Immunized with Gliadin or Ovalbumin

Sjölander, A.; Magnusson, K.-E 284

Endotoxin-Induced Auto-Immunity in Mice. I. Time and Dose Dependence of Production and

Serum Levels of Antibodies against Bromelain-Treated Mouse Erythrocytes and Circulating

Immune Complexes

Bloembergen, P.; Hofhuis, F.M.A.; van Dijk, H.; Verhagen,

C; Rademaker, P.M.; Wülers, J.M.N 291

Thymus Dependence of Compound 48/80-Induced Mucosal

Mast Cell Proliferation

Aldenborg, F 298

Immunogenicity of Hapten-Carrier Conjugates Associated

with Liposomes

Neveu, P.J 306

Expansion of a T Lymphocyte Subpopulation (CD3+,4-,8-)

after Immunodepression Associated with Disseminated

Histoplasmosis

Lehmann, P.F.; Donabedian, H.; Sawyer, T 311

Use of the Cutaneous Anaphylactoid Test to Detect Differences in Mast Cell Mediator-Releasing

Activity among LHRH Peptides

Nekola, M.V.; Morgan, J.E.; O’Neil, C.E.; Hocart, S.J.;

Coy, D.H 316

Short Communication

Isolation of a Histamine-Releasing Factor from Two-Cell Human Embryo

Cocchiara, R.; di Trapani, G; Azzolina, A.; Albeggiani, G.;

Geraci, D 321 
Book Review 324

No. 4

Original Paper

Antibodies to Food and Environmental Antigens in Serum,

Respiratory Tract and Intestine of Pigs

Morgan, K.L.; Patel, D.; Bourne, F.J 325

Lack of IgA Antibody Response in Secretions of Rat Dams during Long-Term Ovalbumin

Feeding. Induction of Systemic Tolerance in Pups but Not in Adult Rats Wold, A.E.; Dahlgren, U.I.H.; Ahlstedt, S.; Hanson, L.Å. 332

Characterization of the Main IgE-Binding Components of Cat

Dander

Duffort, O.; Carreira, J.; Lombardero, M 339

Contents

Hydrocortisone Both Decreases the Up-Regulation of Comple

ment Receptors CR1 and CR3 and the Ingestion Process of

Human Granulocytes

Forslid, J.; Hed, J 345

Functional Heterogeneity among Cytotoxic Clones Derived

from Natural Killer Cells

Christmas, S.E.; Moore, M 351

Age-Dependent Bone Marrow Mast Cell Maturation in Spe

cific Pathogen-Free Rats

Ahlstedt, S.; Håård, J 359

Application of the First International Standard of Dermatophagoides pteronyssinus (House Dust Mite) in the Evalua tion of Allergen Extracts Produced from Two Different

Source Materials

Maasch, H.J.; Wahl, R.; Fuchs, T 363

Lung Nonresponsiveness Produced in Guinea Pigs by Aerosol ized Antigen. I. Nonresponsiveness Is Not Antigen Specific

Blanchard, G.C.; Pathak, S.K.; Gercel Taylor, C; Ber-

man, L.D 373

Inhibition of Histamine Release from Rat Mast Cells by Botu-

linum $\mathrm{C} 2$ Toxin

Böttinger, H.; Reuner, K.-H.; Aktories, K 380

Induction of Photoallergy in Guinea-Pigs by Injection of Pho-

toallergen-Protein Conjugates

Barratt, M.D.; Goodwin, B.F.J.; Lovell, W.W

Inhibition of Antigen-Induced Contraction of Guinea Pig Isolated Tracheal Muscle with 2-n-

butyl-3-dimethylamino-5,6-methylenedioxy indene (MDI-A), indane (MDI-B) and 8-

(diethylamino)octyl-3,4,5-trimethoxy benzoate hydro-chloride (TMB-8)

Nagai, H.; Yakuo, I.; Arimura, A.; Hara, S.; Inagaki, N.;

Koda, A 390

Platelet-Activating Factor in the Inflammatory Exudate in the

Anaphylactic Phase of Allergic Inflammation in Rats 
Watanabe, M.; Ohuchi, K.; Sugidachi, A.; Hirasawa, N.;

Hayashi, Y.; Tsurufuji, S 396

Role of Lymphocytes in the Modulation of the Immunogenicity of Bone Marrow: A Rat Model

Wottge, H.-U.; Müller-Ruchholtz, W 404

Characterization of Trypanosoma cruzi Antigens Recognized by Sera from Patients with Chronic Chagas' Disease

Gea, S.; Rodriguez, P.; Vottero-Cima, E 410

Mediators of C5a-Induced Bronchoconstriction in the Guinea

Pig

Regal, J.F.; Bell, R.L 414

Short Communication

Circulating Basophil Counts in Atopic Individuals

Reilly, K.M.; Yap, P.L.; Dawes, J.; Barnetson, R.S.C.;

MacKenzie, F.; Allan, T.L 424

Book Reviews

427

News Item 428

Author Index 429 